\title{
A FILOSOFIA DO DIREITO EM ROMA
}

\author{
PROF. LUIZ FERNANDO COELHO \\ Assistente de Filosofia do Direito, \\ do Departamento de Direito Privado da \\ Universidade Federal do Paraná
}

\section{§ 1. Introdução}

A jurisprudência romana se desenvolve sob a égide da doutrina do direito natura ${ }^{1}$, na esteira das concepções herdadas do pensamento clássico. No primeiro século antes de Cristo, as idéias dimanadas da cultura grega começam a surtir efeitos na civilização romana, e justamente, como observa RIVAUD, na ordem técnica e na ordem jurídica ${ }^{2}$.

O surgimento dos grandes impérios e decadência da cidadeEstado, a pólis, exigiram nova ética e nova concepção do homem e do Estado; em Roma, as idéias mais ou menos difusas da moral estóica e epicurista, de que os postulados da razão teriam força e alcance universais, encontram ambiência favorável à sua aplicação prática; o direito natural, que não é mais o fundado na idéia do Estado perfeito, e nem o direito da cidade fundado na observação da natureza, o justo natural de ARISTÓTELES, é agora concebido como a própria natureza baseada na razão, traduzida em princípios de valor universal; e os romanos utilizam tal concepção para transformar o seu rígido sistema jurídico num sistema cosmopolita, apto a governar o mundo.

Acostumados a encarar a civiliação romana como a pátria do direito, maravilhados ante a construção técnica da ordem jurídica romana - um dos pilares da civilização ocidental - não se preocuparam os estudiosos com a filosofia do direito dimanada do gênio romano; no contexto da romanística o papel reservado à filosofia é

1. Vid. BATALHA Wilson de Souza Campos, Introduçäo ao Direito, São Paulo, Ed Rev. dos Tribunais, 1968, vol. II, pág. 613. Tb. RÁO Vicente, O Direito e a Vida dos Direjtos, São Paulo, Max Limonád, 1952, vol. I, pág. 79.

2. Cf. RIVAUD Álberto. 
pequeno, em parte porque, de espírito prático, ocupavam-se os romanos em solucionar os problemas do dia-a-dia, na medida em que se apresentavam, e em parte porque, sendo herdeiros da filosofia grega, a sua contribuição neste campo é realmente singela, quando comparada às notáveis construções sistemáticas do pensamento grego.

Salvo as obras de LUCRÉC!O CARO, os tratados de CÍCERO e as obras de SÊNECA, a filosofia propriamente quase não está representada em Roma, sendo que, ao segundo, atribui-se o mérito de ter tornado popular em Roma a filosofia ${ }^{3}$.

Isso não impede todavia de se avaliar a dimensão filosófica do gênio romano, seja para descobrir a parcela de originalidade que the cabe na evolução do pensamento europeu, seja para descobrir e ressaltar os princípios fundamentais implícitos na Jurisprudência romana.

Os princípios da ciência jurídica romana no período clássico derivam da filosofia grega, particularmente, de três doutrinas: o platonismo, o peripatetismo e o estoicismo. Em menor grau, do epicurismo e das diversas escolas socráticas.

Não que os pensadores romanos tenham se agrupado em torno desta ou daquela doutrina, mas que o gênio romano é eclético e demonstra ter assimilado a filosofia dimanada das mais expressivas correntes do pensamento grego.

\section{§ 2. A Infiuência do platonismo}

A visão de uma ordem social hierarquizada, onde cada classe cumpre o seu papel e cada cidadão ocupa o seu lugar, segundo os objetivos imanentes na sua idéia e coerentes com a idéia do todo, nunca deixou de exercer alguma influência, em maior ou menor grau, no pensamento jurídico e político de todas as épocas.

No contexto romano, esta influência é a princípio tímida, chegando a ser predominante no século III da era cristã, quando se afirma a corrente do néo-platonismo, reunindo os nomes de PLOTINO, PORFÍRIO, JAMBLICO, PROCLUS e outros. Finalmente, quando a filosofia cristã, através da patrística, passa a orientar a evolução do pensamento filosófico e jurídico, fá-lo sob a égide do néo-platonismo, em cujo contexto SANTO AGOSTINHO idealiza a Civitas Dei.

3. Vid. DEL VECCHIO Giorgio, Lições de Filosofia do Direito, trad. de Antonio José Brandão, Coimbra, 1959, pág. 66. 
CICERO, pelo seu ecletismo - teria, em sua formação, lido cuidadosamente as obras de PLATÃO, AR!STÓTELES, dos grandes estóicos e epicuristas ${ }^{4}$ - que o torna receptivo a diversas correntes filosóficas, a despeito de sua ética predominantemente estóica, revela a influência platônica na República e nas Leis. E a concepção hierárquica do direito o leva a identificar a ordem jurídica num sistema de leis, derivadas da razão universal, da qual participa a razão dos sábios. Vislumbra-se aqui evidentemente uma combinação da idéia platônica do Estado ideal, cujo governo compete aos sábios, com a doutrina estóica do Logos.

É o início de um novo jusnaturalismo, profundamente diferenciado do direito natural clássico, que teve ampla repercussão no pensamento ocidental.

A doutrina de PLATÃo enfatiza a submissão dos súditos à autoridade governante; no mundo romano, ela serviu para embasar a autoridade imperial, princípio expresso nos adágios qued principi placuit legis habet vigorem ${ }^{5}$ e princeps legibus solułus esì; no mundo cristão, serviu para fundamentar a doutrina da autoridade divina dos reis, segundo a cosmovisão patrística.

Pode-se concluir que é o platonismo que preside, ainda no mundo romano, à mudança de sentido na idéia do direito; identificado com o justo no pensamento clássico e na época em que se inicia propriamente a Jurisprudência romana como ciência - o direito era o jus e, mais tarde, identificado com a lei, expressão do poder governante - o direito como lex.

A influência estóica vai dar novas dimensões a esta concepção hierárquica da ordem jurídica, presidindo o desenvolvimento de uma ciência jurídica axiomatizada e dogmática.

\section{§ 3. A influência do estoicismo}

O estoicismo é sem dúvida a doutrina filosófica de maior penetração no mundo romano; isto se deve em parte à sua proximidade histórica, eis que o apogeu da primeira słoá coincide com a transposição operada no mundo antigo, do centro do mundo civilizado, da Grécia para o Lácio; e em parte porque o humanismo estóico, desconhecendo as fronteiras da antiga cidade-Estado e anulando as diferenças sociais e territoriais entre os homens, encarnou a mundividência de uma nova era, onde a realidade política consubstan-

4. Vid. RIVAUD, ob. cit. pág. 214 .

5. Inst. I, II, 6 . 
cia-se nos grandes impérios, sendo Roma o momento culminante desse processo histórico.

Os grandes jurisconsultos romanos eram estóicos. Acreditavam na supremacia de um Logos, o qual se manifestaria na razão humana, determinando a escolha da virtude. Somente, que o desinteresse estóico pela vida pública e a submissão ao destino não encontraram eco na efervescente e jovem cultura romana; sob a influência de PANÉCIO e POSSIDÔNIO, o humanismo estóico passa a conceber a noção do dever e a determinar a escolha da atitude racionalmente mais aceitável; o estoicismo passivo transforma-se e passa a exercer papel ativo na edificação da ordem social justa.

A maior conseqüência dessa mudança de orientação ocorreu com a teoria do direito natural.

CÍCERO, ele mesmo um estóico, provavelmente discípulo de POSSIDÔN:O, exara a célebre definição, em seu tratado da República: Esi quidem vera lex, recta ratio, nałurae congruens, diffusa in omnes, constans, sempiłerna. A tradução é a seguinte: "Existe uma verdadeira lei, a reta razão, conforme a natureza, difusa em todos, imutável e sempiterna"6. Nesta definição o jurisconsulto identifica a razão com a lei natural, centralizando as tendências estóicas à fundamentação racional de uma visão cosmopolita do direito, do Estado - tornado realidade com a expansão de Roma - e da justiça, preludiando assim o direito natural racionalista oposto ao de fundamentação metafísica da antiga tradição pré-socrática.

A asserção de CÍCERO contraditava o relativismo dos céticos, em especial CARNÉADES; neste ponto a sua posição histórica é análoga à de SÓCRATES, pois ambos procuraram restabelecer a convicção de uma fundamentação absoluta para o direito e a justiça. Essa lei, consubstanciada na razão, constituia o fundamento, não só do jus naturale, como também do jus gentium - observado por todos os povos e do jus civile; não haveria portanto oposição entre as três expressões do jus, pois cada uma delas corresponderia a determinações graduais do mesmo princípio, a recła rałio ${ }^{7}$.

Encontramos um ULPIANO a citação, tornada clássica, que preconiza um direito natural comum a homens e animais quod natura omnia animalia docuit ${ }^{8}$.

Essa idéia de que todos os seres vivos estão sujeitos a uma lei, bem como a um Deus - logos, ratio ou pneuma é um dos prin-

6. CíCERO, De República, III, 2.

7. Vid. DEL VECCHIO, ob. ct. pág. 68.

8. Digesto $1,1,3$. 
cípios fundamentais do estoicismo, difuso na mentalidade romana ${ }^{9}$. Segundo atesta FRIEDRICH, a propósito da citação de ULPIANO, esse princípio dimana de uma concepção da lex ou nomos que não distingue entre o que estamos habituados a considerar como lei da nafureza e normas básicas do direî̉o, mas que concebe ambas como determinantes da natureza das $\operatorname{coisas}^{10}$; e assevera que a transposição do significado da lei da natureza para o sentido que se tornou familiar no ocidente, ocorre a partir de CÍCERO ${ }^{11}$; entretanto os intérpretes do pensamento de CÍCERO se dividem, atribuindo-lhe uns haver identificado o direito natural universal e o direito privado romano, e outros, que ele teria separado a ambos muito clara e definidamente ${ }^{12}$.

$\epsilon$ evidente que resquícios da antiga identificação cosmológica entre a ordem natural e a humana permanecem insinuados no cosmopolitismo estóico, conjugado com o seu racionalismo, o que implica um panlogismo, a noção de que os seres vivos (animalia) participam da ratio universal. Forçoso é porém reconhecer que a trilogia consagrada pela Jurisprudência romana, na esteira de CíCERO e ULPIANO - jus nałurale, jus gentium, jus civile - não significa que esses jurisconsultos reconhecessem a existência de um direito para os animais, porém, somente que a idéia do direito natural é inerente à idéia de ordem que governa todas as criaturas. Esta doutrina repousa inequivocamente no estoicismo, pois os estóicos preconizavam a aplicação da justiça somente aos seres racionais ${ }^{13}$.

No desenvolvimento dessa doutrina chegou a ciência jurídica romana a equiparar o jus gentium ao jus naturale, por considerar este uma implicação da naturalis ratio; assim, GAIO preconizava a divisão bipartite, em que o jus naturale está abrangido pelo jus gentium' ${ }^{14}$; e ULPIANO, a final, acaba por esclarecer que a divisão do direito não trata propriamente de estabelecer três ordens jurídicas, mas tão somente de uma idéia que unifica as expressões do direito criado pelos povos; é por isso que, para ele, a justiça é vontade constante de dar a cada um o seu direito ${ }^{15}$.

No mesmo sentido, CíCERO, ao que parece, concebia as três ordens expressas na tricotomia do direito romano, como dimanadas do mesmo princípio racional, o qual estaria difuso em todos,

9. Vid. FRIEDMANN W. Théorie Générale du Droit, Paris, LGDJ, 1965, pág. 51.

10. Cf. FRIEDRICH, ob. cit. pág. 45.

11. Id.

12. Ibidem

13. Vid. BUSTAMANTE Lino Rodriguez-Arias, Ciência y Filosofia del Derecho, Buenos Aires, EJEA, 1961, pág. 232.

15. Dig. I, 1, 10.

14. GAIO, 1, 1; Inst. 1, 2, 1 . 
segundo se depreende de sua famosa definição do direito natural ${ }^{16}$; não nos parece pois que o conceito ciceroniano do direito positivo pudesse configurar a oposição, característica do jusnaturalismo europeu moderno, ao direito natural; nisto permanece CíCERO fiel à sua filiação racionalista estóica, tendente à universalidade.

A influência estóica caracteriza duplo movimento na Jurisprudência de Roma, aparentemente oposto: por um lado, preside o desenvolvimento da casuística e, por outro, introduz a metodologia dedutiva na interpretação e aplicação das leis, o que ocorreu após a mudança operada na lógica aristotélica, sob a égide da stoá.

A ciência jurídica romana, no início, partia dos topoi, os lugares comuns que fundamentavam a argumentação dialética, base da retórica. O humanismo estóico fez com que os juristas romanos atribuissem maior importância à realidade da vida que se apresentava nos litígios, preocupando-se menos com a preservação dos princípios, ínsitos na metodologia do direito natural; o escopo seria assim, da atividade dos prudentes, da atuação dos magistrados, a solução humana, prática e razoável, das situações concretas. Mas o racionalismo estóico, prevalecendo aos poucos sobre o seu humanismo, olvidou a tópica e transformou a analítica - a que os estóicos chamavam lógica, a partir da silogística aristotélica ampliada e corrigida - no instrumento por excelência da busca da verdade, eterna e imutável, dimanada da razão universal; essa nova metodologia repercutiu na Jurisprudência, transformando-a em dogmática.

Essa mudança de sentido na concepção da ciência do direito ocorreu não sem prejuízo da cauística tradicional, de base tópica, argumentativa e dialética, responsável pela notável organização jurídica romana.

\section{§ 4. A influência do peripatetismo}

Apesar da grande expansão do estoicismo e de ter reunido esta doutrina o maior número de adeptos entre os grandes pensadores, filósofos, poetas, prosadores e juristas, é o filósofo do Liceu quem cataliza a maior parcela de influência na formação do pensamento filosófico e jurídico de Roma.

O predomínio tardio do estoicismo e a evidente ambiência platônica em torno da concepção do poder imperial, acabaram por elidir a influência da filosofia peripatética; mas o fato de ela ter ocor16. Vid. MONTORO André Franco, Introdução à Ciência do Direiło, São Paulo, Liv. Martins
Ed. 1970 Vol. I, pág. 339 e seg. 
rido nos primórdios do processo histórico de sistematização da ordem jurídica dos romanos e ter presidido a afirmação do direito romano como sistema científico, fez com que a caracterização geral do pensamento filosófico-jurídico ficasse eivada dos princípios da filosofia de ARISTÓTELES.

O caráter eclético do pensamento romanista favoreceu a expansão do peripatetismo. O próprio CÍCERO, estóico, escreveu uma Tópica, dedicada ao jurista TREBATIUS, inspirado em grande parte na Tópica aristotélica ${ }^{17}$. E a concepção ciceroniana do Estado é uma renovação da doutrina aristotélica, pois, para o jurisconsulto romano, o homem está naturalmente impelido, por instinto natural, para a convivência política ${ }^{18}$.

O historiador POLÍBIO, para explicar a expansão territorial e o poderio de Roma, elaborou uma teoria da gênese do direito e do Estado, inspirado em ARISTÓTELES; em 156 a.C. um dos mais ilustres sucessores do Estagirita na direção de sua escola do Liceu, CRITOLAOS, foi mandado a Roma como embaixador dos atenienses, em companhia de DIÓGENES de Babilônia, estóico, e CARNÉADES, da escola de PLATÃO. Essa embaixada causou grande interesse e teve a maior repercusão em Roma, pois reuniam-se na mesma ocasião os chefes das três mais importantes escolas filosóficas da Gré$\mathrm{cia}^{19}$. E as escolas de retórica, em Roma, divulgavam a filosofia aristotélica e a sua compreensão do direito e da justiça.

A formação da Jurisprudência como sistema científico absorveu destarte as noções aristélicas da justiça e da eqüidade, concebendo-se inicialmente o direito como dimanado do justo e não da norma. A seguinte expressão, contida no Digesto, o evidencia: lus non a regula sumatur, sec ex jure, quod est, regula fiat ${ }^{20}$.

A despeito das alterações de conteúdo procedidas pelos estóicos, o pensamento romano definiu o direito como ars boni et aequi, na fórmula de $\mathrm{CELSO}^{21}$, justi atque injusti scientia, segundo ULPIA$\mathrm{NO}^{22}$.

A teoria estóica do direito natural fundado na razão, na verdade apenas atribuiu conteúdo racionalista à distinção aristotélica entre o justo natural e o justo por lei.

17. Vid. VIEHWEG Theodor, Tópica y Jurisprudencia, trad. de L.D. Ponce de Leon, Madrid, Taurus, pág. 39.

18. Vid. DEL VECCHIO, ob. cit. pág. 68.

19. Vid. MOREAU Joseph, Aristóteles $y$ su escuela, trad. de Marino Ayerra, Buenos Aires, EUDEEBA, 1972, pág, pág. 265.

20. Dig. $50,17,1$

21. Dig. 1. 1 .

22. Inst. I, 1. pr. 
A influência mais importante entretanto, da filosofia de ARISTÓTELES, se manifestou na caracterização geral da Jurisprudência romana como sistema científico; e isso ocorreu em dois momentos, os quais correspondem aos dois sentidos que tomou a evolução da lógica peripatética, após a morte do mestre, e também à concepção do direito em dois planos, o do justo e o do normativo.

ARISTOTELES havia dedicado as duas Análíticas ao silogismo apodítico e a Tópica ao silogismo dialético. Por razões históricas cujo processo tem início entre os discípulos do filósofo, sendo incrementado pelo racionalismo estóico, preocupado com a verdade eterna e imutável fundada no Logos, a silogística contida nas Analíticas foi destacada e desenvolveu-se fora do contexto da obra aristotélica, sendo aos poucos olvidados os seus estudos dedicados aos tópicos. Isto fez com que o modo de pensar típico do mundo ocidental ficasse impregnado da idéia de sistema e da necessidade de fundar todo - conhecimento científico em métodos analíticos e princípios apodícticos.

Ora, o pensamento problemático e argumentativo, base da retórica, a mais nobre das artes no mundo antigo, constituia o núcleo da Jurisprudência. Sistematizado na Tópica, presidia a busca do justo nas situações concretas; o processo de elaboração do direito admitia o recurso aos textos, dimanados das decisões pretorianas, dos comícios ou do senado; e, ainda dentro da doutrina do Liceu, admitia-se a correção dos textos em nome da aequitas, a confrontação de opiniões e a consideração casuística e circunstncial das situações concretas; a atividade dos primeiros prudentes limitava-se a respondere, cavere, agere, no tocante às quaestiones que os cidadãos Ihes submetiam.

A mesma tendência se observa na obra dos legisladores; as primeiras leis restringem-se à previsão de uma série de casos particulares; disso é exemplo a lei Aquilia; e a consideração das normas leges - pelos prudentes levava em conta a coerência das soluções com a realização do jusìo.

Esta fora a filosofia jurídica correspondente ao conceito do direito como expressão da justiça, e que encontrou na Tópica a sua fundamentação lógica; a construção sistemática do direito romano, inspirado na consideração gradual das necessidades sociais, tendendo à solução dos litígios na medida em que iam se apresentando e em grau crescente de complexidade, foi o resultado dessa filosofia.

É que o modo de pensar tópico, o do pensamento argumentativo que tem o problema por ponto de referência, corresponde à es- 
trutura espiritual que predominava na antigüidade, como o demonstrou VICO em 1708 e VIEHWEG, nos nossos dias ${ }^{23}$.

Num segundo momento a lógica estóica passou a preponderar, e a mentalidade jurídica romana substituiu aos poucos a dialética que Ihe vinha do Estagirita, pela metodologia analítica, também aristotélica, mas já com o novo alcance que lhe haviam dado os estóicos; nesse novo contexto, a fonte do direito não seria mais a natureza ${ }^{24}$, mas a lex, e o direito positivo deixaria de ser concebido de maneira pragmática como obra de juris prudentia - a busca do justo conforme a natureza - e passaria a constituir um sistema formal axiomatizado, onde as soluções jurídicas seriam o resultado do trabalho racional, dedutivo, a partir dos princípios expressados nas regras.

Tal mentalidade prevaleceu sobre a concepção tópica e dialética ainda no tempo de JUSTINIANO; a obra do imperador, consubstanciada no Codex e nas Novelae, e a sua própria atitude avessa ao trabalho hermenêutico dos jurisconsultos ${ }^{25}$, bem o demonstra.

A moderna Jurisprudência ocidental manteve a mentalidade analítica, traduzida na redução do direito ao sistema jurídico-positivo, concebendo a lei como fonte primeira do direito em nome da segurança das relações jurídicas, e a ciência do direito como dogmática jurídica.

É deveras sintomático que, no momento em que se pretende restaurar a autenticidade do pensamento aristotélico, se descobre na Tópica e na teoria da argumentação dialética a gênese do modo de pensar característico da Jurisprudência.

\section{$\S$ 5. Conclusão}

As correntes do pensamentos filosófico grego convergem para a Jurisprudência romana e, através dela, para o direito ocidental; da mesma forma, os princípios gerais em que se assentam os sistemas jurídicos das nações modernas e a própria ciência do direito estudada e praticada hodiernamente, dimanam dos fundamentos lançados pelos gregos, absorvidos pelos romanos e cultivados pela civilização cristã. Roma é assim a ponte entre o mundo antigo e a civilização ocidental.

À guisa de conclusão, tentaremos resumir estes princípios.

A noção do direito natural, que representa o denominador co-

23. Vid. VIEHWEG Theodor, ob. ct.

24. GAIO 1, 1-Dig. 1, 1.

25. De Confirmatione Digestorum. Constitutio Tanta. Esp. 22. 
mum do pensamento filosófico, político e jurídico na antiguidade greco- romana é sem dúvida o mais importante; ela persiste por todas as escolas e manifestações da sabedoria grega e romana, mesmo nos movimentos negativistas da sofística e do ceticismo antigo. No mundo romano, essa idéia do direito natural é incorporada à Jurisprudência, sendo que todas as concepções que a expressaram, das mais variadas formas, são cultivadas pelos juristas, filósofos e literatos romanos.

O segundo princípio é a racionalidade, cuja incorporação ao direito, encarado como sistema e a ciência jurídica como dogmática, ocorreu no mundo romano, embora suas raízes estejam na analítica aristotélica e na ética estóica.

Finalmente, o terceiro dos princípios gerais do direito ocidental é a noção da justiça vinculada ao conceito do direito. Este princípio está ligado ao primeiro, o do direito natural, e o alcance que se the atribui é ainda implicação da racionalidade que caracterizou a ordem jurídica e a Jurisprudência a partir de certa época na história do direito romano.

Seja no sentido subjetivo, de gênese platônica, ou no objetivo, de origem pitagórica e aristotélica, o conteúdo valorativo do direito esteve sempre relacionado com a idéia de justiça, a partir da primitiva identificação entre as duas noções, na mitologia e na física dos jônios antigos e posteriores. Trata-se porém de um ponto em que o direito moderno parece desvincular-se de suas origens, pois a concepção legalista e dogmática enfatizou o princípio da racionalidade levando-o às últimas consequências, quando, no direito romano, estava ela delimitada e coerente com a idéia do direito natural e do jus - o direito como o justo.

Isso não obstante, a tradição ocidental está profundamente impregnada da idéia da justiça como conteúdo do direito, e é à luz desta noção que exsurgem as críticas às ordens jurídicas consideradas injustas ou ilegítimas; é à luz a identificação entre o direito e - justo que se questiona a legitimidade das leis atentatórias aos direitos humanos e sistemas jurídicos segregacionaistas e instituidores de privilégios aristocráticos.

Vimos como essa compreensão profunda e humana do fenômeno jurídico presidiu a formação e desenvolvimento da ordem jurídica dos romanos e de sua Jurisprudência, o que configura a maior dignidade de nossa Ciência do Direito.

Passada a época de crise do direito contemporâneo, a revisão que ora se processa em torno dos seus fundamentos constitui na verdade uma tentativa de retornar às origens greco-romanas, quando 
- direito significava justiça e a Jurisprudência era a ciência e a técnica da solução razoável, prudencial, equilibrada e justa dos litígios sociais.

Uma ordem jurídica adequada às necessidades do mundo de hoje em transformação, cada vez mais unificado numa sociedade global, não pode prescindir do princípio da Justiça, o que implica a restauração do velho conceito do direito como dikaion e como jus. 